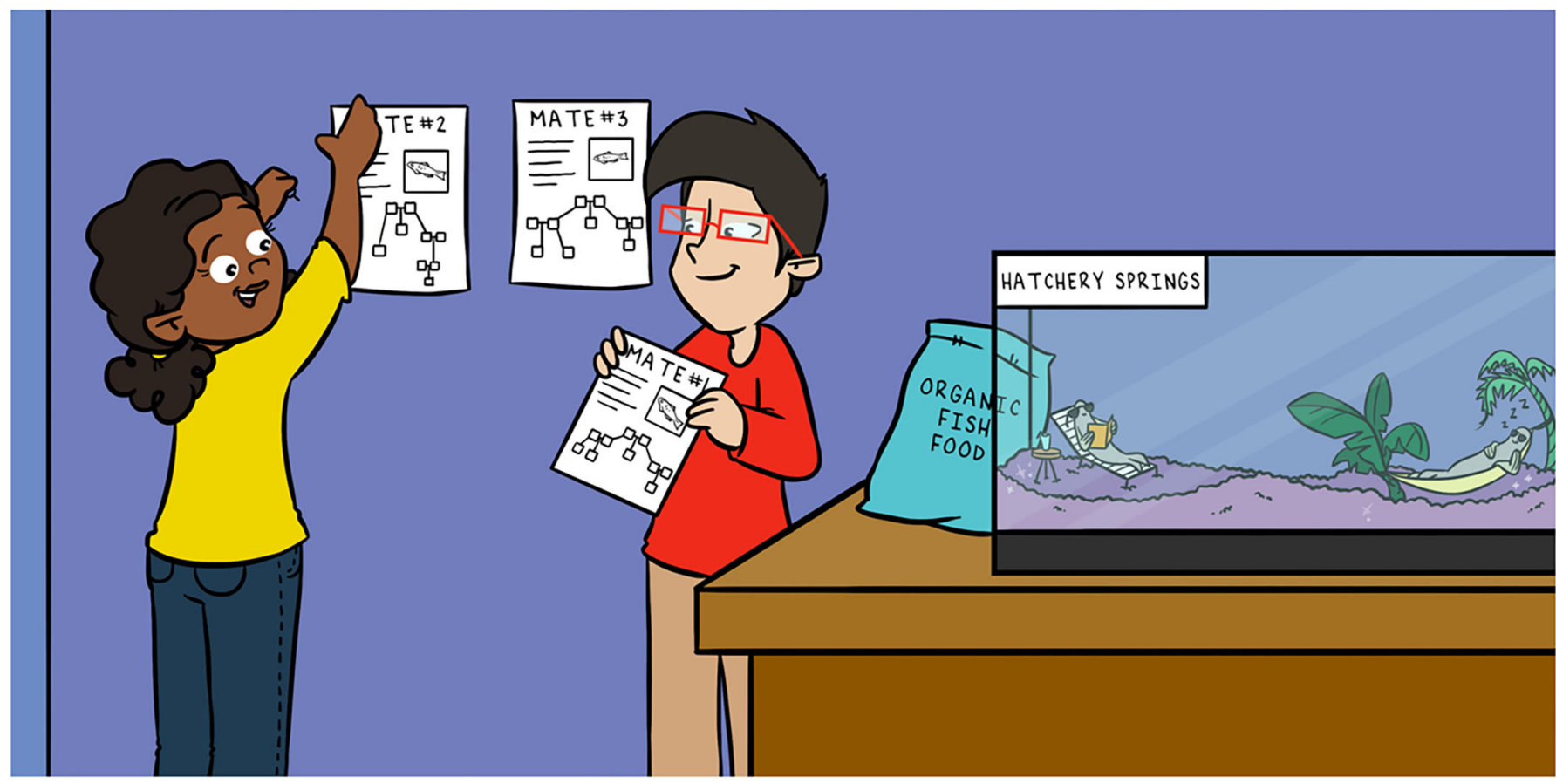

\title{
DIARY OF WIMPY FISH: HOW TO GROW UP IN A CONSERVATION HATCHERY AND SURVIVE IN THE REAL WORLD
}

\section{Amanda J. Finger ${ }^{1 *}$, Daphne A. Gille ${ }^{2}$, Nicole M. Kwan ${ }^{2}$ and Melinda R. Baerwald ${ }^{2}$}

${ }^{1}$ Genomic Variation Laboratory, Department of Animal Science, University of California, Davis, Davis, CA, United States ${ }^{2}$ Division of Integrated Science and Engineering, California Department of Water Resources, West Sacramento, CA, United States

\section{YOUNG REVIEWERS:}

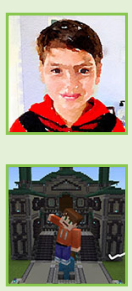

ETHAN

AGE: 8

LANGSTON

AGE: 12
Conservation hatcheries are like luxury fish hotels that raise threatened and endangered fish that are nearing extinction in the wild. Raising fish in the controlled environment of the conservation hatchery usually takes away the issues that caused the population to dwindle in the first place. However, there is one problem: the fish get used to the conservation hatchery and become wimpy, meaning they become domesticated and do not do as well as wild fish in if they are returned to the natural environment. Managing the genes of hatchery fish is one way to block domestication and raise fish that are as close as possible to wild fish. In the San Francisco Estuary watershed, there are conservation hatcheries for the endangered delta smelt and winter-run Chinook salmon. Read on to learn about how these conservation hatcheries help hatchery fish be as tough as possible and survive in the wild. 
1 See https:// restorationfund. org/programs/ hatchery/ or https://www fws.gov/ fisheries/nfhs/ imperiled_species. html.

2 See https://www. fws.gov/ fisheries/nfhs/ fish_production. html.

\section{GENERATION}

A group of individuals born and living at about the same time. Within your family, your grandparents are one, your parents are a second, and you are a third generation.

\section{GENETIC}

\section{MANAGEMENT}

Specific actions taken by humans to maintain genetic diversity and avoid inbreeding in a population, so that the population can succeed over time.

\section{WHAT IS A CONSERVATION HATCHERY?}

When a species is threatened or endangered, it is at risk of becoming extinct. Extinction means that an organism disappears forever. If we see that a species is dying off, what can we do to stop it from becoming extinct? Unfortunately, this question is coming up more and more. The United States has laws in place (mainly, the Endangered Species Act) to make sure that threatened and endangered species are protected and that there is a plan with specific actions to help the populations improve. One possible action for fish species that are at risk of extinction is to raise them in a conservation hatchery, or luxury fish hotel, and later release them into the wild. Conservation hatcheries $^{1}$ are different from production hatcheries ${ }^{2}$. The goal of production hatcheries is to make as many fish as possible for food or fishing. Instead, the goal of a conservation hatchery is to raise fish that are as similar as possible to wild fish of the same species, but in a controlled environment. This is done so that hatchery fish can survive and mate when they are released into the wild. This may sound easy, but most hatchery fish do not do well in the wild.

\section{THE DOMESTICATION DILEMMA}

Have you ever gone on a long vacation that was so fun and relaxing it was hard to go back to the stress of school and everyday life? This is what happens to fish that are raised in a hatchery. In the wild, fish are always dealing with changing environmental conditions, like how cloudy the water is and changes in water temperature. Conditions can be different by the month, day, or even hour! Fish in the wild must also watch out for predators like large fish and birds, all while making sure to find enough food. It is much different in the hatchery. The hatchery environment is like a fancy resort with a private chef who serves all-you-can-eat meals, located on an island with mild water temperatures year-round and no bullies (predators) allowed. Fish can live for many generations in the hatchery and they get used to the easy hatchery lifestyle. This adaptation to the hatchery, called domestication, can make it very difficult for the fish to return to the harsh natural environment because they have become, well, wimpy [1].

What can we do to limit domestication and toughen fish up to prepare them to return to the dog-eat-dog world of the natural environment? One option is to raise fish in tanks that look like wild habitats, with plants, rocks, and other natural features to encourage more natural behavior [2]. We can also train fish to avoid predators, like a self-defense class. The hope is that one or more of these changes will lead to higher survival in the wild. However, the most important thing a conservation hatchery can do to boost survival is called genetic management. 
Figure 1

To help maintain genetic diversity in conservation hatcheries, fish receive a special tag and are genetically analyzed. Based on the results, decisions are made about which fish should be mated together. The goal is not to mate fish that are close relatives, to avoid inbreeding. Inbreeding can result in a loss of genetic diversity, which can make fish wimpy.
GENETIC DIVERSITY

Variation in DNA among individuals or populations. For example, differences in human eye color and butterfly wing color depend on genetic diversity.

\section{Using Genetic Management at Hatcheries}

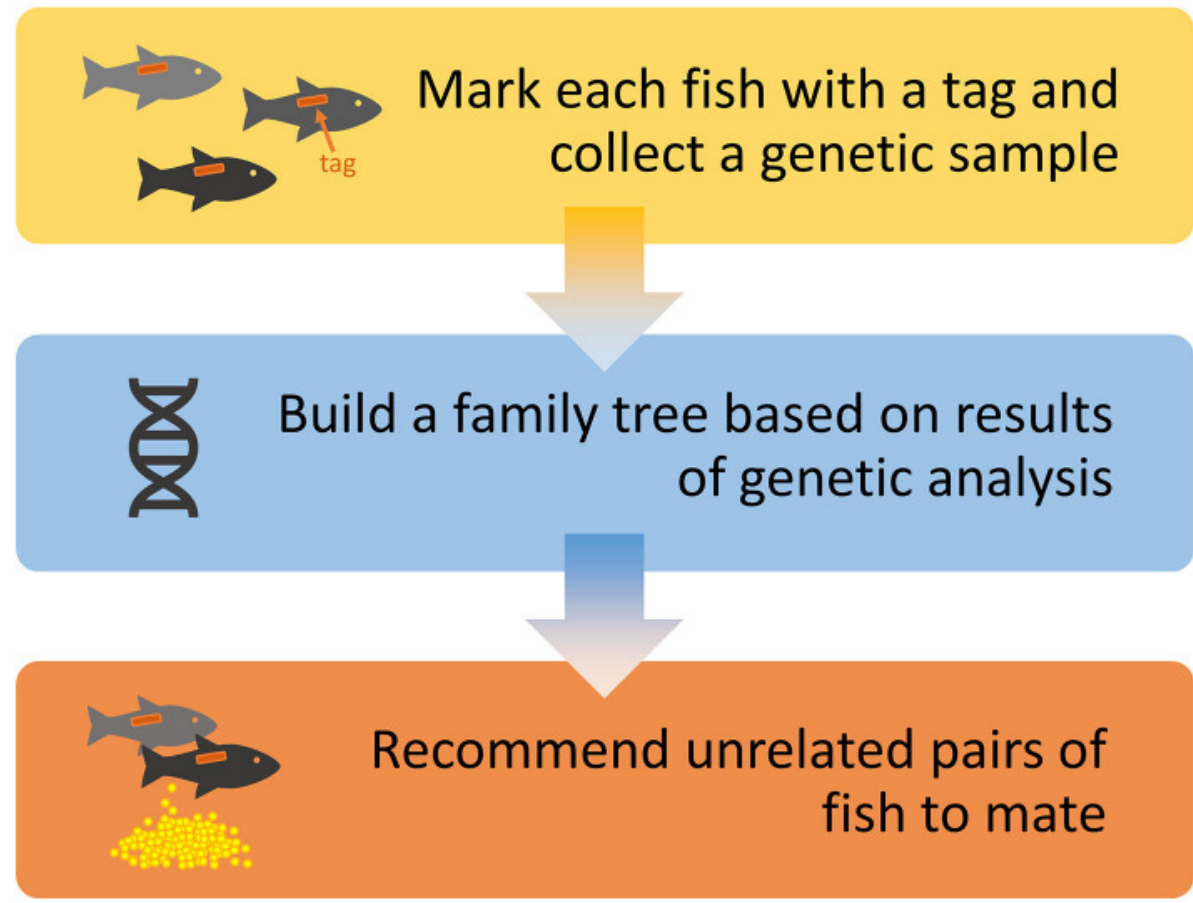

Figure 1

\section{CONSERVATION HATCHERIES USE GENETIC MANAGEMENT}

You have probably heard of DNA and how it contains the code for all your physical traits, like your height and eye color. What you may not know is that every population has a unique genetic signature that is shared by individuals in that population. Over generations, the genetic signature of fish that live in the easy, constant hatchery environment will be different from fish that live in the wild. Also, by only taking a portion of fish from the wild population, there will be less genetic diversity in the hatchery population compared to the wild population. Genetic diversity is important for a population because populations with more genetic diversity have a bigger "toolkit" for survival and responding to their environment.

Genetic management can be done in many ways, but the idea is to mate fish that are not related to each other, to try to keep genetic diversity high. The goal of genetic management is to make fish that are better prepared to survive in the wild. To do genetic management, a small tag with an ID is inserted into the fish and then a tiny piece of a fish's fin is taken for genetic analysis. The DNA from the fin sample tells us the fish's family tree, and which other fish would be good mates (Figure 1). More wild fish can also be brought in as mates to "refresh" the genetics of the hatchery population. 


\section{Figure 2}

\section{Conservation}

hatcheries and the San Francisco Estuary. The Livingston Stone

National Fish Hatchery is located at the base of Shasta Dam, along the Sacramento River. The Fish Conservation and Culture Laboratory is located east of the San Francisco Estuary, next to the pumps that send water from the Estuary down to central and southern California.

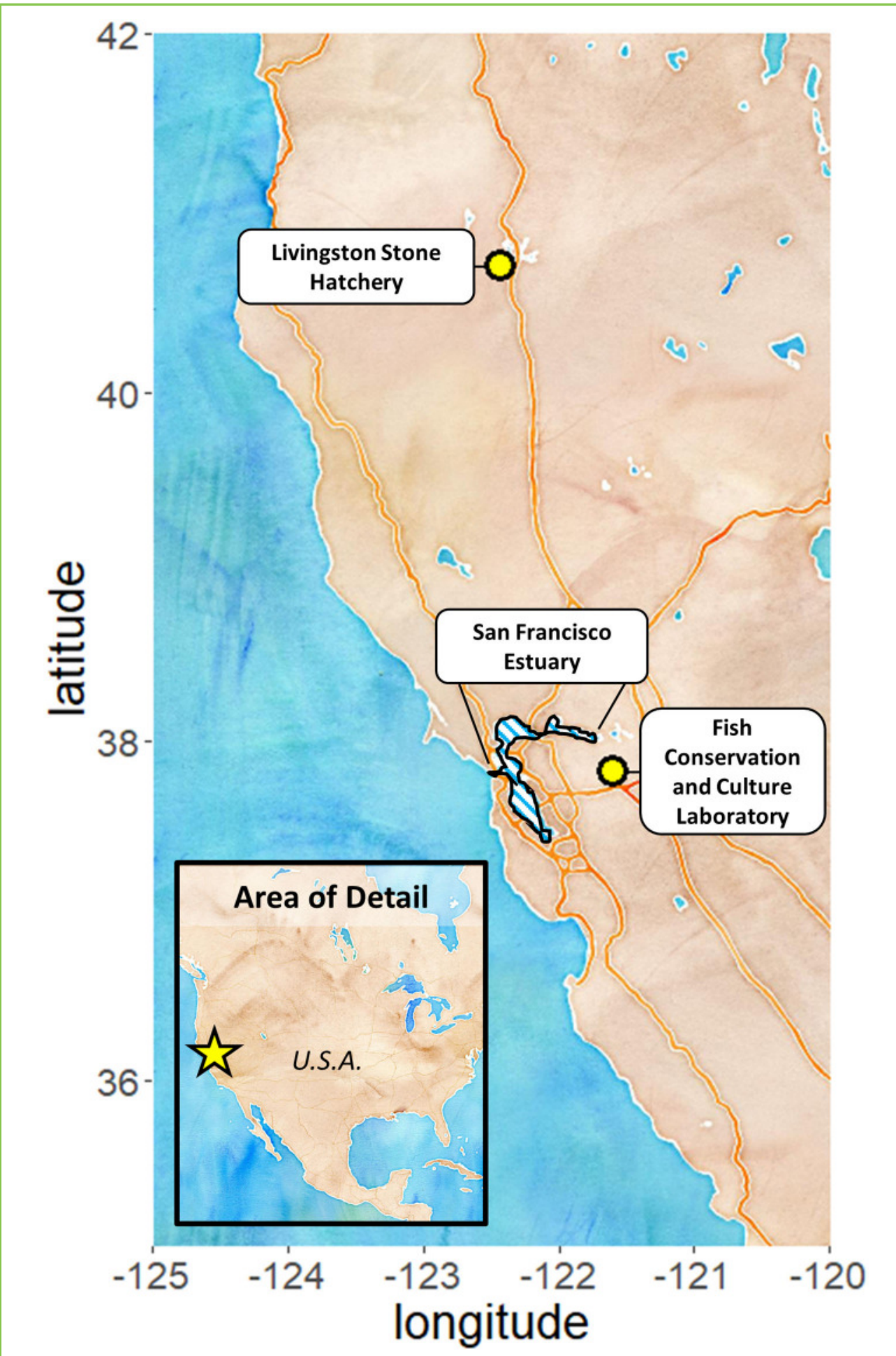

Figure 2

\section{DELTA SMELT, A SMALL WIMPY FISH}

Right now, there are two fish species that can only be found in the San Francisco Estuary and are being raised in conservation hatcheries: delta smelt and winter-run Chinook salmon (Figure 2). 
3 https://fccl. ucdavis.edu/

\section{INBREEDING}

Breeding between close relatives. Over time, inbreeding can reduce genetic diversity, which can have negative consequences.
The delta smelt is a small ( $<3$ inches), silvery fish. They typically live for just 1 year and if you get really close to one, they smell like cucumbers! Unfortunately, humans have changed the Estuary through pollution from farming, the introduction of non-native species, and by pumping water out of the Estuary. These changes make it harder for native species like delta smelt to live there. There are now so few delta smelt that they are classified as endangered under the California Endangered Species Act. In 2006, a conservation hatchery for delta smelt called the Fish Conservation and Culture Laboratory ("Fish Lab") ${ }^{3}$ was built to prevent extinction, even if delta smelt disappear from the wild.

The Fish Lab uses genetic management to maintain a healthy population of delta smelt and avoid domestication [3]. Every year, wild delta smelt are captured and mated with delta smelt from the hatchery, to keep the genetic signatures of the two populations as similar as possible. Also, genetic analysis is done so that only unrelated males and females are mated, to make sure that genetic diversity is not lost by inbreeding. Today the Fish Lab is in its 14th generation of delta smelt, and this hatchery population is needed more than ever as the wild population grows smaller and smaller. Thousands of acres of tidal wetland habitat are being restored to help create a better home for the species. The Fish Lab is also preparing to make thousands more delta smelt, so that they can be released to supplement the wild population in the next few years.

\section{WINTER-RUN CHINOOK SALMON, A LARGE (NOT SO) WIMPY FISH}

Chinook salmon are found in the northern Pacific Ocean and range from the Central Valley in California, north along the coast of Canada and Alaska, all the way to the western Pacific. This species can grow to be very large (up to 5 feet!) and is popular with fishermen because of the delicious and nutritious meat. Chinook salmon hatch from eggs in freshwater streams, swim out to the ocean, and then return to the same freshwater streams to spawn (reproduce). The season in which Chinook salmon migrate back to freshwater is called a "run." There are four Chinook salmon runs in the Central Valley: spring, fall, late-fall, and winter. In the past, there were large numbers of winter-run Chinook salmon in the Sacramento River and tributaries. However, the building of the Shasta and Keswick dams in the 1940s blocked these fish from reaching their natural spawning streams. Since then, winter-run have only been able to spawn below the Keswich dam, where the water temperatures are too warm for most eggs to survive. Winter-run numbers are now so low that these fish are listed as endangered under the federal Endangered Species Act.

To boost numbers of winter-run, a conservation hatchery program was started in 1991. Today, wild fish are caught and mated at the Livingston Stone National Fish Hatchery at the bottom of Shasta Dam. 


\section{Figure 3}

Conservation

hatcheries are just one part of saving species from extinction. Poor habitat conditions in the San Francisco Estuary led to the decline of delta smelt and winter-run

Chinook salmon populations. While conservation

hatcheries can protect these endangered species and eventually reintroduce them into the wild, habitat improvements must also be performed to help species recover.

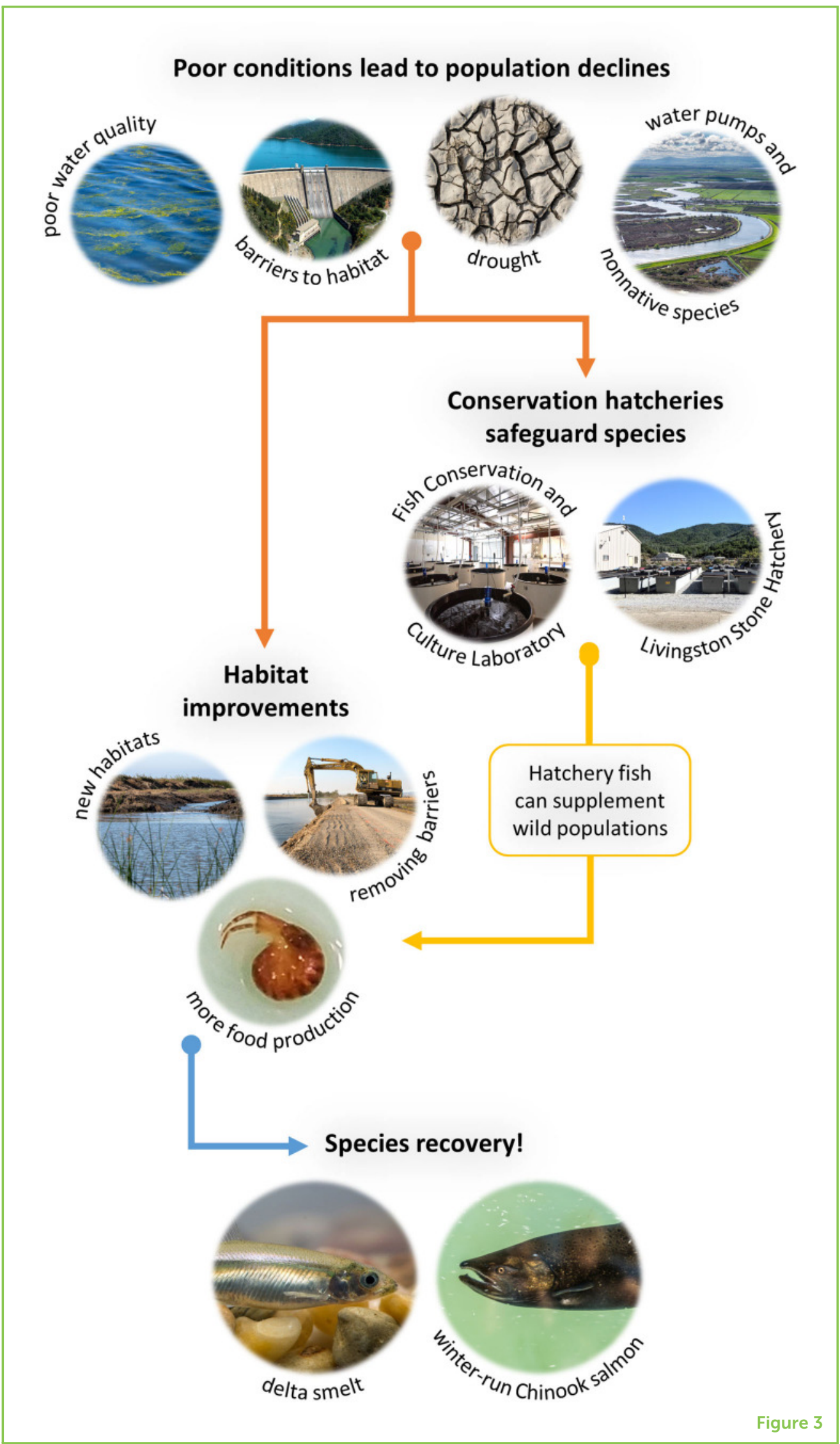


The offspring from these matings are raised in the Hatchery and then returned to the Sacramento River and other associated streams as young fish. Much like at the Fish Lab, genetic analysis tells the Hatchery staff which fish are unrelated and can be mated together to limit domestication, loss of genetic diversity, and inbreeding. However, the Hatchery uses a mating strategy in which eggs from one female are separated into two groups and mixed with the sperm from two different males individually. Doing matings this way can capture even more genetic diversity than matings with a single male and female. While no salmon can truly be called wimpy, hatchery salmon typically do not survive and reproduce as well in the wild as do wild salmon [4]. There is still a long way to go, but conservation hatchery programs have helped stop the extinction of winter-run Chinook salmon.

\section{A RAY OF HOPE}

While conservation hatcheries are a useful tool, these hatcheries alone cannot save a species from extinction. Instead, these hatcheries should be used along with other tools and strategies, like creating better habitats and fixing the problems that led to the species decline in the first place (Figure 3). By working together and using conservation hatcheries wisely, we can find ways to keep endangered fish from vanishing completely. Preserving fish species is critical because they are an important part of our ecosystems.

\section{REFERENCES}

1. Christie, M. R., Marine, M. L., French, R. A., and Blouin, M. S. 2011. Genetic adaptation to captivity can occur in a single generation. Proc. Natl. Acad. Sci. U.S.A. 109:238-42. doi: 10.1073/pnas.1111073109

2. Flagg, T. A., and Nash, C. F. (editors). 1999. A Conceptual Framework for Conservation Hatchery Strategies for Pacific Salmonids. U.S. Department of Commerce. Seattle, WA: NOAA Technical Memorandum NMFS-NWFSC-38, 54 p.

3. Finger, A. J., Mahardja, B., Fisch, K. M., Benjamin, A., Lindberg, J., Ellison, L., et al. 2018. A conservation hatchery population of Delta Smelt shows evidence of genetic adaptation to captivity after 9 generations. J. Heredity 109:689-99. doi: 10.1093/jhered/esy035

4. Araki, H., Berejikian, B. A., Ford, M. J., and Blouin, M. S. 2008. Fitness of hatchery-reared salmonids in the wild. Evolutionary Appl. 1:342-55. doi: 10.1111/j.1752-4571.2008.00026.x

SUBMITTED: 30 September 2020; ACCEPTED: 09 September 2021; PUBLISHED ONLINE: 18 October 2021.

EDITED BY: Pedro Morais, University of Algarve, Portugal

CITATION: Finger AJ, Gille DA, Kwan NM and Baerwald MR (2021) Diary of Wimpy Fish: How to Grow Up in a Conservation Hatchery and Survive in the Real World. Front. Young Minds 9:612102. doi: 10.3389/frym.2021.612102 


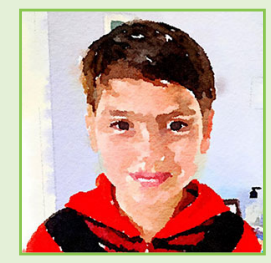

CONFLICT OF INTEREST: The authors declare that the research was conducted in the absence of any commercial or financial relationships that could be construed as a potential conflict of interest.

COPYRIGHT () 2021 Finger, Gille, Kwan and Baerwald. This is an open-access article distributed under the terms of the Creative Commons Attribution License (CC BY). The use, distribution or reproduction in other forums is permitted, provided the original author(s) and the copyright owner(s) are credited and that the original publication in this journal is cited, in accordance with accepted academic practice. No use, distribution or reproduction is permitted which does not comply with these terms.

\section{YOUNG REVIEWERS}

\section{ETHAN, AGE: 8}

My name is Ethan. I play the piano and take martial arts classes. I like science and to read. My favorite thing to do is to celebrate my friends' birthday parties and to play soccer with my team. I have two miniature Holland Lop bunnies. I love sharks and when I am old, I want to be a conservation biologist.

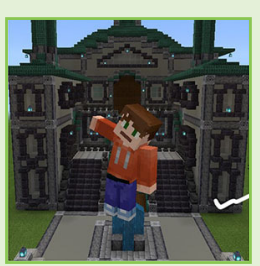

\section{LANGSTON, AGE: 12}

My name is Langston and I am 12 years old. Some of the things I like to do include playing sports and video games. My favorite subject is math. When I grow up I want to be an architect.

\section{AUTHORS}

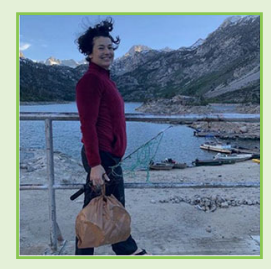

\section{AMANDA J. FINGER}

I am a research scientist at University of California, Davis. I enjoy thinking about how threatened and endangered populations have changed over time, and I use genetics to answer questions about why populations are the way that they are, and how we can protect them for future generations. My preference is to work with aquatic species, because unlike birds and land animals, we know that they are in water so they are easier to find! When I am not working, I enjoy traveling the world, rock climbing, and puttering around my home in Sacramento, California. *ajfinger@ucdavis.edu

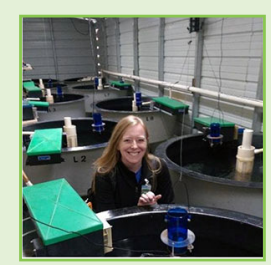

\section{DAPHNE A. GILLE}

I am an environmental program manager at the California Department of Water Resources. In my job, I spend a lot of time thinking about how science can be used to better our understanding and help our management of threatened and endangered species. I work as part of a large team of scientists that monitors the health of the San Francisco Estuary by looking at changes in fish populations and water quality. In my free time, I enjoy spending time with my family, hiking and camping in our coastal redwood forests, and making and eating pie! 


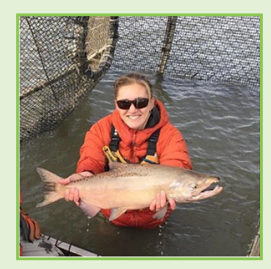

\section{NICOLE M. KWAN}

I am a fisheries ecologist with the California Department of Water Resources. I am passionate about helping advance fisheries science to help native species in decline. At work, I often put on waders and head out into the field to sample fish in river and floodplain habitats. The data from these sampling projects are an important part of monitoring native and endangered species and informing actions to improve their populations. In my free time, I enjoy running with my dog, doing DIY projects, and traveling.

\section{MELINDA R. BAERWALD}

Two things I feel passionate about are the conservation of threatened species and learning new things about our world through science. I am lucky because in my job as an environmental program manager for the California Department of Water Resources, I get to do both! I like to use genetic approaches to aid species and my research projects have focused on topics such as migration, predation, and disease. My dream species I would love to study is the mountain gorilla. In my free time I like to hike, garden, read, and visit the ocean. 